\title{
Optimization of Keratinase Production for Feather Degradation by Bacillus subtilis
}

\author{
Somayeh Mousavi ${ }^{1}$, Mojtaba Salouti ${ }^{2, *}$, Reza Shapoury $^{2}$, Zahra Heidari $^{2}$ \\ ${ }^{1}$ Department of Microbiology, Faculty of Sciences, Zanjan Branch, Islamic Azad University, Zanjan, IR Iran \\ 2 Biology Research Center, Zanjan Branch, Islamic Azad University, Zanjan, IR Iran \\ *Corresponding author: Mojtaba Salouti, Biology Research Center, Zanjan Branch, Islamic Azad University, Zanjan, IR Iran, Tel./Fax: +98-2414261221, E-mail: saloutim@yahoo.com.
}

Received: July 12, 2012; Revised: October 27, 2012; Accepted: December 8, 2012

\begin{abstract}
Background: The feather is an environmental pollutant that can be degraded by bacterial and fungal microorganisms. The keratin sheets constitute $90 \%$ of the feather mass. Due to the extremely rigid structure, keratin is insoluble and hard to degrade. Some microorganisms such as Bacillus spp. were reported to be able to degrade keratin by secretion of keratinase.

Objectives: The aim of this study was the isolation of feather degrading Bacillus spp. from a poultry waste and the optimization of conditions for the highest enzyme activity and feather degradation.

Materials and Methods: The microorganisms were isolated from the waste of a poultry in Miyaneh, Iran, and the Bacillus spp. were identified using morphological, physiological and biochemical tests. The Bacillus spp. cultured in a medium consisted of feather at $\mathrm{pH}$ 7.4 and $27^{\circ} \mathrm{C}$ for seven days to identify the feather-degrading Bacillus spp. The biochemical tests were performed to determine the strain of the bacterium. The study was repeated under different $\mathrm{pH}$ and temperatures to find the optimum conditions for best enzyme activity. Results: The PCR approved the Bacillus genus of the isolates. The strain of Bacillus subtilis was identified using biochemical tests. $40^{\circ} \mathrm{C}$ and $\mathrm{pH} 11$ are the optimum condition for maximum keratinase enzyme activity.

Conclusions: $B$. subtilis was found to be able to degrade the feather.
\end{abstract}

Keywords: Feather Degradation; ; Keratinase Enzyme; Optimization

\section{Background}

The environment and its role on human lives is an important phenomenon (1). Million tons of feathers generated annually by the livestock industry leads to troublesome environmental pollution and wastage of protein-rich reserve (2). The poultry feathers are dumped, used for land filling and incinerated or buried, which involves problems in storage, handling, emission control and ash disposal (3). Discarded feathers also cause various infections including chlorosis, mycoplasmosis and fowl cholera (4). Feather contains over 90\% of crude protein in the form of keratin (2). Keratin is an insoluble fibrous protein which is rich in beta helical extensively cross-linked by disulfide, hydrogen and hydrophobic bonds (3). Hence, it is extremely resistant to degradation by common proteolytic enzymes such as trypsin, pepsin, and papain.

Despite the rigid structure of keratinin, it can be degraded by means of mechanical, chemical and biological methods. The major demerit of mechanical and chemical degradation methods over biological procedures is that certain amino acids might be destroyed that leads to low protein quality and digestibility (5). Keratinase enzymes belong to the hydrolase class which is able to hydrolyse insoluble keratins more efficient than other proteases (6). Biodegradation of poultry waste by keratinases is an environmentally friendly process that can play an important role in biotechnological applications such as enzymatic improvement of feather meal, production of rare amino acids (serine, cysteine and proline), peptides, used in the leather industry as well as medicine and cosmetic production. Alternatively, they can be used in the conversion of feathers into value-added products including fertilizers, glues, films and foils (5). It is also used to eliminate poultry industry contaminations and also be used as a nitrogen fertilizer for plants (5).

Today, with increased earth's emissions and its problems, the use of microorganisms to degrade these pollutants has been considered (7). The most of fungi that

Implication for health policy/practice/research/medical education:

The environment and its role in human life is something that cannot be passed simply. Several million tons of feathers generated annually by the livestock industry leads to troublesome environmental pollution and wastage of protein-rich reserve. The poultry feathers are dumped, used for land filling and incinerated or buried, which involves problems in storage, handling, emission control and ash disposal. Discarded feathers also cause various human ailments including chlorosis, mycoplasmosis and fowl cholera. Feather contains over $90 \%$ of crude protein in the form of keratin. Biodegradation of poultry waste by keratinases is an environment friendly biotechnological process that can play an important role in biotechnological applications such as enzymatic improvement of feather meal, production of rare amino acids (serine, cysteine and proline), peptides, in the leather industry as well as in medicine and cosmetic production.

Copyright (C 2013, Ahvaz JundishapurUniversity of Medical Sciences; Published by Kowsar Corp. This is an open-access article distributed under the terms of the Creative Commons Attribution License, which permits unrestricted use, distribution, and reproduction in any medium, provided the original work is properly cited. 
produce keratinases are pathogenic (7). Hence, many researchers have focused on the potential use of keratinase with bacterial origin (8). The studies have shown that $B a$ cillus spp. have special advantages for the degradation of feather due to its safety and the capacity to secrete large amounts of keratinases directly into the medium (9). Biodegradation of feathers by this bacterium represents a method for improving the utilization of feathers as a feed protein. There are not any reported researches from Iran in the field of feather degradation by Bacillus spp.

\section{Objectives}

The aim of this study was to identify the keratinase-producer Bacillus spp. for feather degradation and optimization the condition for the highest enzyme activity.

\section{Materials and Methods}

\subsection{Isolation of Feather-Degrading Bacillus Species From Poultry Waste}

The soil samples were collected from various poultry and chick farm wastes from different sites of Miyaneh, Iran. The feather medium used for isolation, maintenance, growth and fermentation analysis of the featherdegrading microorganisms contained: $0.5 \mathrm{~g}$ of $\mathrm{NH}_{4} \mathrm{Cl}$, $0.5 \mathrm{~g}$ of NaCl, $0.3 \mathrm{~g}$ of $\mathrm{K}_{2} \mathrm{HPO}_{4}, 0.4 \mathrm{~g}$ of $\mathrm{KH}_{2} \mathrm{PO}_{4}, 0.1 \mathrm{~g}$ of $\mathrm{MgCl} \cdot 6 \mathrm{H}_{2} \mathrm{O}$ and $10 \mathrm{~g}$ of hammer-milled chicken feathers per litre. The $\mathrm{pH}$ was adjusted to 7.5. The mixture was incubated at $27^{\circ} \mathrm{C}$ for 7 days (10). For measurement of degraded keratin, protein concentration was determined by the Bio-Rad protein assay method as described by Bradford. UV-visible spectroscopy was carried out at $595 \mathrm{~nm}$. The determination of protein concentration was performed at the first, third and sixth days of incubation. The Bacillus species exhibiting the highest activity were selected and bacterial identification was conducted based on morphological, physiological and biochemical tests $(11,12)$.

\subsection{SDS-PAGE Analysis}

Sodium Dodesyl Sulfate-Polyacrylamid gel electrophoresis (SDS-PAGE) was carried out for identifying and confirming the production of keratinase enzyme by Bacillus spp. The mineral medium containing feather was centrifuged at $2500 \times \mathrm{g}$ for 20 minutes. The supernatants were loaded on SDS-PAGE. SDS-PAGE was carried out on polyacrylamide slab gel consisting of $10 \%$ separating gel and $4 \%$ stacking gel (13). The molecules with standard weights were $\beta$-Galactosidase (120 KD), Bovine Serum Albumin (85 $\mathrm{KD})$, Ovalbumin (50 KD), Cardonic anhydrase (35 KD), $\beta$ lactoglobuline (25 KD) and Lysozyme (20 KD).

\subsubsection{S rRNA Gene Sequencing Analysis}

PCR method was used for approving the genus of the bacteria. The length of this gene in most species of Bacillus is 1500 base pairs (bp) that contains a high percentage of GC (14). Genomic DNA of the bacteria was extracted according to the boiling method. The bacteria were cultured in the liquid Brain Heart Infusion (BHI, Merck, Germany) medium at $37^{\circ} \mathrm{C}$ for 24 hours. Then, $1 \mathrm{~mL}$ of cells was removed and centrifuged at $10,000 \times \mathrm{g}$ for 2 minutes and transferred to alcohol solution and $50 \mu \mathrm{L}$ of sterile was added to it. The final solution was shacked and boiled for 5 minutes and centrifuged for 3 minutes at 12000 $\times \mathrm{g}$. The supernatant containing DNA was transferred to a new microtubule. The specific gene fragments for $16 \mathrm{~S}$ rRNA-coding regions amplified by PCR using the following primers, (CinnaGen, Iran):

\section{F: 5'-GAGTTTGATCCTGGCTCAG-3}

\section{R: 5'-AGAAAGGAGGTGATCC-3}

The PCR solution, containing $5 \mu \mathrm{L}$ of DNA template, $2 \mu \mathrm{L}$ of Primer Forward, $2 \mu \mathrm{L}$ of Primer Reverse, $2 \mu \mathrm{L}$ of PCR buffer, $0.75 \mu \mathrm{L}$ of $\mathrm{MgCl}_{2}, 0.2 \mu \mathrm{L}$ of Taq, $0.25 \mu \mathrm{L}$ of dNTP and $15 \mu \mathrm{L}$ of deionized $\mathrm{H}_{2} \mathrm{O}$, was prepared and PCR reactions were performed under the following program: initial denaturation for 3 minutes at $94^{\circ} \mathrm{C}$, denaturation for 1 minutes at $94^{\circ} \mathrm{C}$, primer annealing for 1 minute at $58^{\circ} \mathrm{C}$, primer extension for 2 minutes at $72{ }^{\circ} \mathrm{C}$. The last three steps were repeated for 30 cycles and finally, final elongation was done for 10 minutes at $72^{\circ} \mathrm{C}(15)$.

\subsection{Optimization of Keratinase Activity and Feath- er Degradation}

\subsection{1. pH Optimization}

The effect of $\mathrm{pH}$ on enzyme activity was carried out by incubating the enzyme solution at different $\mathrm{pH}$ levels. The mineral medium $\mathrm{pH}$ was adjusted to $7,8,9,10,11$ and 12. Two $\mathrm{mL}$ of a 0.5 McFarland turbidity of the isolated $\mathrm{Ba}$ cillus species was added to each culture and the samples were incubated at $26^{\circ} \mathrm{C}$. Then, the enzyme activity was determined by the Bio-Rad protein assay at each $\mathrm{pH}$ as described by Bradford. Each experiment was repeated three times (16).

\subsubsection{Temperature Optimization}

At optimum $\mathrm{pH}$, the optimal temperature was determined by incubating the enzyme solution and feather at different temperatures ranged from 20 to $45^{\circ} \mathrm{C}$. Then, the enzyme activity was determined by the Bio-Rad protein assay as described by Bradford at different temperatures. Each experiment was repeated three times (17).

\subsection{Statistical Analysis}

The data was analyzed statistically using ANOVA test. The 2-sided P values were calculated and statistical significance was accepted within $95 \%$ of confidence intervals. 


\section{Results}

\subsection{Isolation and Identification of Feather-Degrad- ing Bacillus Species From Poultry Waste}

One out of 5 isolated bacterial strains was found to be able to degrade the feather according to the obtained results of Bradford assay and SDS-PAGE. The strain of the isolated bacterium was identified as Bacillus subtilis based on cellular morphology and several biochemical tests (Table 1 ).

\begin{tabular}{ll} 
Table 1. The Results of Biochemical Tests for the Isolated Bacte- \\
ria \\
\hline Bacillus subtilis & Test \\
\hline+ & Catalase \\
+ & V-P reaction \\
- & Growth in anaerobic \\
+ & Growth at $50^{\circ} \mathrm{C}$ \\
+ & Growth in $7 \% \mathrm{NaCl}$ \\
\hline- & Acid and gas from glucose \\
+ & NO ${ }_{3}$ reduced to $\mathrm{NO}_{2}$ \\
+ & Starch hydrolyzed \\
\hline- & Growth at $65^{\circ} \mathrm{C}$ \\
\hline- & Rods $1.0 \mu$ m wide or wider \\
\hline V & pH in V-P medium $<6.0$ \\
+ & Hydrolysis of casein \\
\hline
\end{tabular}

\subsection{SDS-PAGE}

SDS-PAGE analysis showed a monomeric protein with a molecular weight of $35 \mathrm{kDa}$ which was similar to that described by Ana et al. during keratinases production by $B$. licheniformis (Figure 1).

\subsubsection{S rRNAGene Sequencing}

After DNA extraction and PCR, agarose gel electrophoresis was carried out to analysis the products of 16S rRNA PCR. A band with a molecular weight of $1500 \mathrm{bp}$ was observed that was belonged to the Bacillus genus (Figure 2).

\subsection{Optimization of Enzyme Activity}

\subsection{1. $\mathrm{pH}$}

The results showed that the $\mathrm{pH} 11$ at the sixth day of culturing was the optimal $\mathrm{pH}$ for maximum activity of keratinise enzyme in feather degrading $(\mathrm{P}<0.05)$ (Figure 3).
Figure 1. SDS-PAGE of Keratinase Enzyme

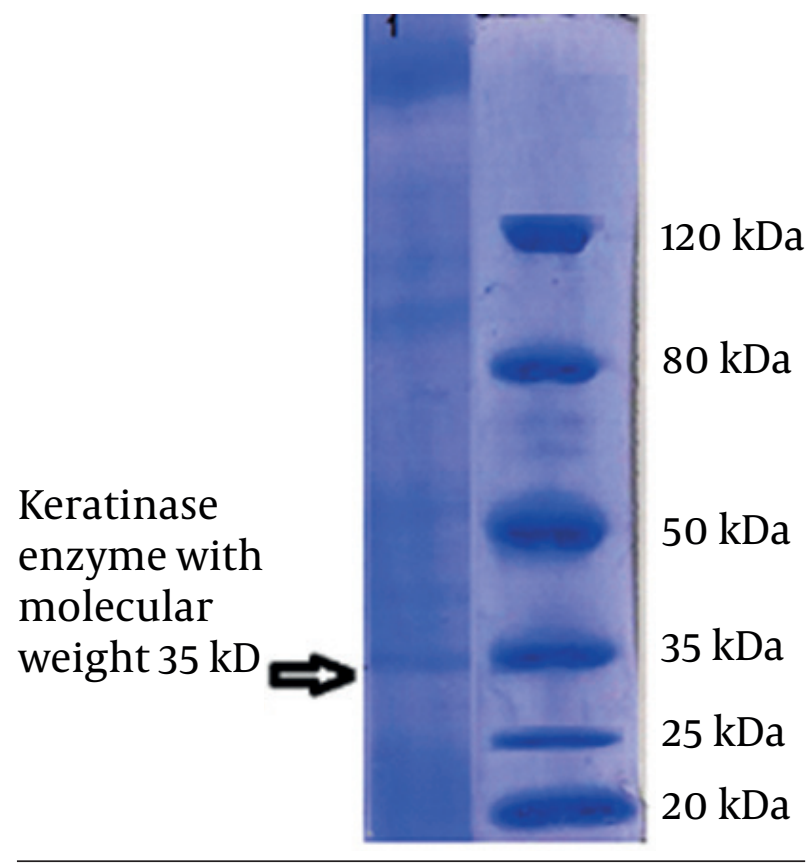

Column 1: B. subtilis. Lane M: molecular weight marker proteins: $\beta$-galactosidase (120 KD), bovine serum albumin ( $85 \mathrm{KD}$ ), ovalbumin (50 $\mathrm{KD})$, cardonic anhydrase (35 KD), $\beta$-lactoglobuline (25 KD), lysozyme (20 $\mathrm{KD})$

Figure 2. Electrophoresis of 16S rRNA PCR of Isolated Bacillus

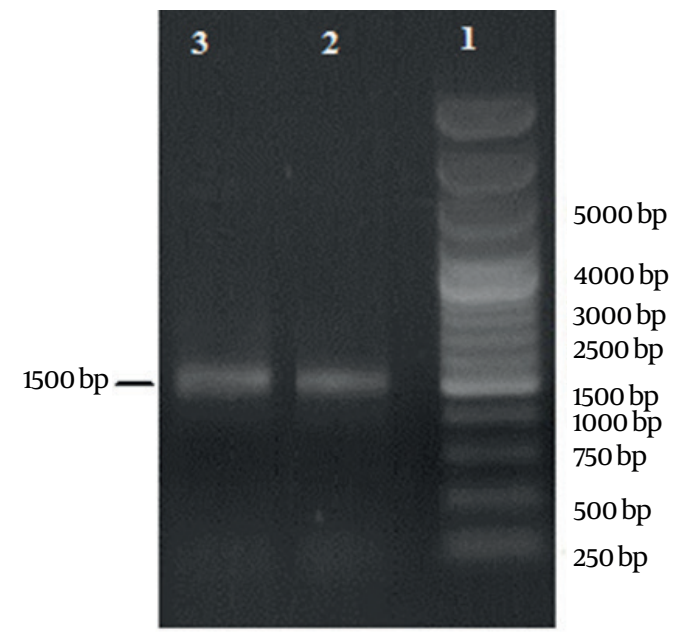

First column: size markers, second column: B. subtilis, third column: $B$. subtilis subsp. subtilis ATTC6051. 
Bacillus Subtilis

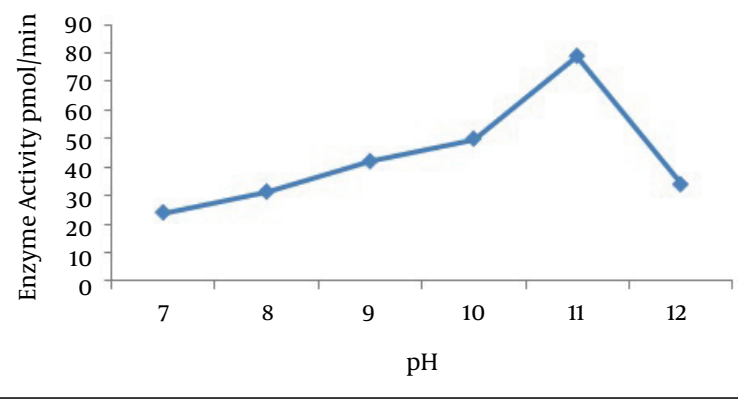

Figure 3. Activity of Keratinase Enzyme at Different pH for Feather Degrading on Day 6After Feather-Incubation

\subsubsection{Temperature}

In Figure 4, the optimum temperature of keratinase activity has been shown. The results showed that temperature of $40^{\circ} \mathrm{C}$ on the sixth day of culturing is the best condition for maximum activity of keratinize enzyme considering to death phase and sporulation of the bacteria $(\mathrm{P}<0.05)$.

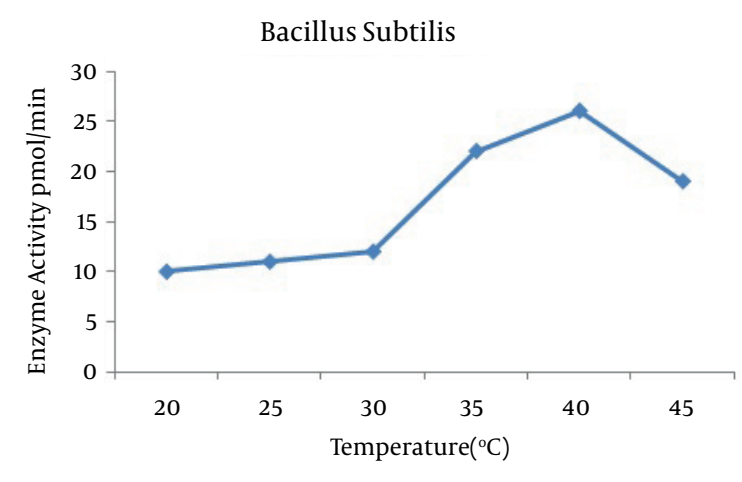

Figure 4. Activity of Keratinase Enzyme at Different Temperatures for Feather Degrading During a 6 Day- Incubation With Feather

\section{Discussion}

Although many microbial resources are able to produce keratinase, but a few of those have industrial values. Bacillus species are one of the best keratinase producers that have high enzyme secretion capacity (20 to $25 \mathrm{~g} / \mathrm{L}$ ) among microbial recourse (18). In previous studies by Zhao in 1998, Evans in 2000 and Ichida in 2001, it has been shown that Bacillus spp. has high keratinase activity $(16,18,19)$. In 2001, Kim et al. isolated keratinase producer Bacillus from soil of a poultry waste unit (20).

In this study, Bacillus spp. isolated from one unit of poultry waste in city of Miyaneh, Iran. The bacteria were cultured in a sterile culture containing feather. Among the five isolated Bacillus spp. one strain was found to produce keratinase using feathers as a sole carbon and nitrogen source that identified as B. subtilis based on morphological and biochemical characteristics and 16S rRNA sequence analysis. SDS-PAGE analysis illustrated a monomeric protein form with a molecular weight of 35 $\mathrm{kDa}$ similar to B. licheniformis described by Ana et al. (3).

The physical factors such as $\mathrm{pH}$ and incubation temperature were found to be effective on keratinase activity (10). To determine the optimum $\mathrm{pH}$ for highest enzyme activity, B. subtilis was cultured in a mineral medium with sterile feather at different pH. B. subtilis had the highest enzyme activity at $\mathrm{pH} 11$ at the sixth day of incubation. $\mathrm{Ba}$ cillus spp. usually show optimum keratinase production at temperatures ranging from 30 to $50^{\circ} \mathrm{C}(2,21,22)$. In this study, the enzyme production was studied over a broad range of temperature $\left(20-45^{\circ} \mathrm{C}\right)$ and optimum temperature was determined for $B$. subtilis at $40^{\circ} \mathrm{C}$ at the sixth day of incubation. The results showed that $B$. subtilis can be used as a potential candidate for degradation of feather. The optimum condition for keratinase activity was determined at $\mathrm{pH} 11$ and $40^{\circ} \mathrm{C}$.

\section{Acknowledgements}

None declared.

\section{Authors' Contribution}

Mojtaba Salouti developed the original idea and the protocol, abstracted and analyzed data, revised the manuscript, and is guarantor. Somayeh Mousavi performed the experiments and wrote the preliminary manuscript. Reza Shapouri and Zahra Heidari were the advisor and helped to design the protocol and perform the experiments.

\section{Financial Disclosure}

Authors have no relevant financial interests related to the materials in the manuscript.

\section{Role of sponsors}

The funding organizations are public institutions and had no role in the design and conduct of the study; collection, management, and analysis of the data; or preparation, review, and of the manuscript.

\section{Funding/Support}

There were not any financial and material support for the research and work.

\section{References}

1. Kansoh AL, Hossiny EN, Abd EL-Hameed EK. Keratinase Production From Feathers Wastes Using Some Local Streptomyces Isolates. Aust J Basic Appl Sci. 2009;3(2):561-71.

2. Cai CG, Lou BG, Zheng XD. Keratinase production and keratin degradation by a mutant strain of Bacillus subtilis. J Zhejiang Univ Sci B. 2008;9(1):60-7.

3. Mazotto AnaMaria, Coelho RosalieReedRodrigues, Cedrola SabrinaMartinsLage, de Lima MarcosFde Lima, Couri Sonia, Paragua de Souza Edilma, et al. Keratinase Production by Three Bacillus 
spp. Using Feather Meal and Whole Feather as Substrate in a Submerged Fermentation. Enzyme Res. 2011;2011:7.

4. Xu B, Zhong Q, Tang X, Yang Y, Huang Z. Isolation and characterization of a new keratinolytic bacterium that exhibits significant feather-degrading capability. Afr J Biotechnol. 2009;8(18):4590-6.

5. Zerdani I, Faid M, Malki A. Feather wastes digestion by new isolated strains Bacillus sp in Morocco. Afr J Biotechnol. 2004;3(1):67-70.

6. Vigneshwaran C, Shanmugam S, Sathish KT. Screening and characterization of keratinase from Bacillus licheniformis isolated from Namakkal poultry farm. Researcher. 2010;2(4):89-96.

7. Lin X, Lee CG, Casale ES, Shih JC. Purification and Characterization of a Keratinase from a Feather-Degrading Bacillus licheniformis Strain. Appl Environ Microbiol.1992;58(10):3271-5.

8. Esawy MA. Isolation and partial characterization of extracellular keratinase from a novel mesophilic Streptomyces albus AZA. Res JAgric Biol Sci. 2007;3(6):808-17.

9. Agrahari S, Wadhwa N. Degradation of Chicken Feather a Poultry Waste Product by Keratinolytic Bacteria Isolated from Dumping Site at Ghazipur Poultry Processing Plant. Int J Poult Sci. 2010;9:482-9.

10. Kim JM, Lim WJ, Suh HJ. Feather-degrading Bacillus species from poultry waste. Process Biochem. 2001;37(3):287-91.

11. Riffel A, Brandelli A. Isolation and characterization of a featherdegrading bacterium from the poultry processing industry. J Ind Microbiol Biotechnol. 2002;29(5):255-8.

12. Riffel Alessandro, Brandelli Adriano. Keratinolytic bacteria isolated from feather waste. Brazil J Microbiol. 2006;37:395-9.

13. Harde SM, Bajaj IB, Singhal RS. Optimization of fermentative production of keratinase from Bacillus Subtilis NCIM 2724. Agric Food Anal Bacteriol. 2011;1(1):54-65.
14. Ni H, Chen $\mathrm{Q}$, Chen F, Fu M, Dong Y, Cai H. Improved keratinase production for feather degradation by Bacillus licheniformis ZJUEL31410 in submerged Cultivation. Afr J Biotechnol. 2011;10(37):7236-44

15. Kainoor PS, Naik GR. Production and characterization of feather degrading keratinase from Bacillus sp. JB 99 . India J Biotechnol. 2010;9(4):384-90.

16. Evans KL, Crowder J, Miller ES. Subtilisins of Bacillus spp. hydrolyze keratin and allow growth on feathers. Can J Microbiol. 2000;46(11):1004-11.

17. Mozammel Hoq Md, Siddiquee KAZ, Kawasaki H, Seki T. Keratinolytic activity of some newly isolated Bacillus species.J Biologic Sci. 2005;5(2):193-200.

18. Zhao L, Qi J, Gao J. A kinetics study on the production of alkaline proteinase by Bacillus licheniformis 2709. Chin J Biotechnol. 1998;14(4):241-7.

19. Ichida JM, Krizova L, LeFevre CA, Keener HM, Elwell DL, Burtt $\mathrm{EH}$, Jr. Bacterial inoculum enhances keratin degradation and biofilm formation in poultry compost. J Microbiol Methods. 2001;47(2):199-208

20. Yamamura S, Morita Y, Hasan Q, Rao SR, Murakami Y, Yokoyama $\mathrm{K}$, et al. Characterization of a new keratin-degrading bacterium isolated from deer fur.J Biosci Bioeng. 2002;93(6):595-600.

21. Suntornsuk W, Suntornsuk L. Feather degradation by Bacillus sp. FK 46 in submerged cultivation. Bioresour Technol. 2003;86(3):239-43.

22. Williams CM, Richter CS, Mackenzie JM, Shih JC. Isolation, identification, and characterization of a feather-degrading bacterium. Appl Environ Microbiol.1990;56(6):1509-15. 